Nig. J. Biotech. Vol. 33 (2017) 125-130

ISSN: 01891731

Available online at

http://www.ajol.info/index.php/njb/index

and www.biotechsocietynigeria.org

DOI: https://dx.doi.org/10.4314/v33i1.18

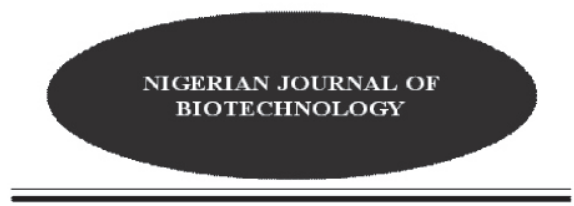

\title{
Association between Insulin Like Growth Factor-1 (IGF-1) gene polymorphism and carcass traits in improved Nigerian indigenous chickens
}

\author{
Wheto, M. ${ }^{1}$, Adenaike, A. S. ${ }^{1}$, Sanda, A. J. ${ }^{1}$, Ilori, B.M. ${ }^{1}$, Akano, ${ }^{2}{ }^{2}$, Sanni, \\ T.1, Olowofeso, 0.1, Ikeobi, C. O. N.1 and Adebambo, O. A. ${ }^{1}$ \\ ${ }^{1}$ Department of Animal Breeding and Genetics, Federal University of Agriculture, Abeokuta, Ogun \\ State, Nigeria. ${ }^{2}$ Department of Agricultural Education, Michael Otedola College of Primary \\ Education, Noforija, Epe, Lagos State, Nigeria \\ (Received: 28:06:2017; Accepted:04 :07:2017)
}

Copyright resides with the authors in terms of the Creative Commons License 4.0.
See http://creativecommons.org/licenses/by/4.0/
Condition of use: The user may copy, distribute, transmit and adapt the work, but must recognize the
authors and the Nigerian Journal of Biotechnology

\begin{abstract}
The insulin-like growth factor-1 (IGF1) is a key regulator of muscle development and metabolism in birds and other vertebrate. Our objective was to determine the association between IGF1 gene polymorphism and carcass traits in FUNAAB Alpha chicken. Genomic DNA was extracted from the blood of $\mathbf{5 0}$ normal feathered birds. At $\mathbf{1 0}$ weeks, the birds were slaughtered for carcass traits. Specific primers for chicken IGF1 were used for amplification of a 622 base segment. The amplified gene products were digested with Hinf1 restriction enzyme and the digested fragments were genotyped. Allele frequencies were $52 \%$ and $\mathbf{4 8} \%$ for A and B, respectively. Genotype frequencies were $\mathbf{2 7} \%, \mathbf{5 0} \%$ and $\mathbf{2 3} \%$ for $A A, A B$ and BB genotypes, respectively. All carcass traits values and the IGF1 gene polymorphism observed were subjected to analysis of variance and the mean were separated using Duncan Multiple Range Test. The results showed that the occurrence of the polymorphism did not affect all the carcass traits but AB genotypes had the highest carcass traits values than the AA and BB genotypes. The conclusion of this study demonstrated that IGF-1 gene, to some extent, could be a candidate gene that affects carcass traits in Improved Nigerian indigenous chicken.
\end{abstract}

Keywords: IGF-1, PCR-RFLP, indigenous chicken

Correspondence: whetom@funaab.edu.ng

\section{Introduction}

The major objective of any animal breeder is to select superior animals for breeding purpose (Hossein and Mohsen, 2011). This is because variation exists among animals including poultry. This variation between animals is important to the genes which offspring received from their parents and with the progeny performance they can be selected through chromosomal part (Nie et al., 2002).

Nigeria indigenous chickens are known to be dual-purpose bird that is used both for meat and egg production in the rural and peri-urban area of the country. They are found in large numbers distributed across different agro ecological categories under a traditional family scavenging management system (Sonaiya and Olori, 1990).
The indigenous poultry species represent valuable resources for livestock development because their extensive genetic diversity allows rearing of poultry under varied environmental conditions, providing a range of products and functions (Sonaiya et al., 1999). The Nigeria indigenous chicken has also been said to be small bodied, slow growing, poor feed converters and poor meat animals (Nwosu and Asuquo, 1985).

Nevertheless, these chickens in Nigeria are major source of raw materials from which sustainable protein supply can be developed within the nation, making this as a matter of concentration for researchers as $90 \%$ of the 150 million chicken in Nigeria are the local variety which contribute $90 \%$ and $72 \%$ of the egg and meat consumed, respectively (Nwanta et al., 2006). 
These findings have led to the conclusion that the indigenous chickens have a great potential for meaningful genetic improvement for growth and therefore contribute to the reduction of protein dearth in the country (Ikeobi et al., 1996).

FUNAAB Alpha strains of chicken was developed at the Poultry Breeding units of the Directorate of the University farm, Federal University of Agriculture, Abeokuta, Ogun state in Nigeria. The selection process for the traits of interest which is the meat and the egg started around 1997 with over 10 generations of selection for improved meat and egg production.

The egg type is a dual purpose which was developed through a rigorous, systematic and selective breeding of the Nigerian indigenous chicken without eroding their tropical adaptive features and disease resistance traits.

The potential variability that exists among the indigenous chickens were utilized to upgrade them. They still maintained the different plumage colours and the three feathering pattern (Normal feathered, frizzled feathered and naked neck) exhibited by the Nigerian Indigenous chicken.

The average chick weight at hatch is between $30-35 \mathrm{~g}$, age at first lay ranged between $16-18$ weeks, average body weight at first lay is between $1200 \mathrm{~g}-1728 \mathrm{~g}$, and weight of first egg at lay is between $35-40 \mathrm{~g}$. The average egg laid per year ranges between $200-250$ eggs.

This increasing interest in genetics and animal breeding has led to several researches on how to improve both productive and reproductive traits in chicken. Some of these productive traits include leanness of chicken carcasses, changes in body weight and linear body parameters.

The chicken IGF-I gene maps to $165.95 \mathrm{cM}$ on chromosome 1 and a QTL at $150 \mathrm{cM}$ on chromosome 1 affecting abdominal fat weight has been detected in chicken (Ikeobi et al., 2002). According to Zhou et al. (2005) revealed four exons and three introns. This gene is said to be a candidate for growth, body composition, metabolism, carcass characteristics, growth of adipose tissue and fat deposition in chicken.

Therefore, IGF-1 gene could be a very useful physiological indicator to assist in screening and selection of animals at an early stage of growth. (Afolayan and Fogerty, 2008). Hence, this study was conducted for identification of the IGF-1 polymorphism and its possible association with carcass traits in improved Nigerian indigenous chicken.

\section{Materials and methods}

Experimental birds and study location

The experiment birds consist of fifty (50) Nigerian improved indigenous chickens. The experiment was carried out at the Poultry breeding unit of the Directorate of University Farm (DUFARMS) and the Biotechnology Center Laboratory of the Federal University of Agriculture, Abeokuta (FUNAAB), Ogun state, Nigeria. The University is located within latitude $7^{\circ} 10^{\prime} \mathrm{N}$ and longitude $3^{\circ} 2^{\prime} \mathrm{E}$ and lies in the south western part of Nigeria. It has an average temperature of $33.7^{\circ} \mathrm{C}$ and relative humidity of $80 \%$ with rainfall of about 1037 $\mathrm{mm}$.

The vegetation in the University represents an interphase between the tropical rainforest and the derived savannah (Goggle Earth, 2016).

\section{Blood collection}

For DNA extraction, blood samples were collected in EDTA-treated tubes from the 10 week-old birds before slaughter. Samples were collected using a syringe from the right jugular vein with a new needle and syringe for each individual to avoid cross contamination.

\section{Genomic DNA Extraction and Quantification}

DNA was extracted from the whole blood using Qiagen DNA extraction kit following the manufacturer protocol. The purity and concentration of the extracted DNA were determined using Nano-drop spectrophotometer.

\section{PCR-RFLP assay:}

The PCR primers specific for the chicken IGF-1 gene were used (Forward: 5 GACTATACAGAAAGAACCAC-3; Reverse: 5TATCACTCAAGTGGCTCAAGT-3) (Nagaraja et al., 2000). The DNA amplification by PCR of each bird was performed according to the following conditions: the PCR was performed in a total volume of $20 \mu \mathrm{l}$, containing $2 \mu \mathrm{l}$ of genomic DNA, $2 \mu \mathrm{l}$ of forward and reverse primer $(10 \mathrm{pmol} / \mu \mathrm{l}), 4 \mu \mathrm{l}$ of $5 \mathrm{X}$ Firepol PCR premix and $12 \mu \mathrm{l}$ of nuclease free water. Cycle parameters were $94^{\circ} \mathrm{C}$ for 5 min then 35 cycles of $94^{\circ} \mathrm{C}$ for $45 \mathrm{sec}, 60^{\circ} \mathrm{C}$ for $45 \mathrm{sec}$ and $72^{\circ} \mathrm{C}$ for 1 min, with a final extension step for $10 \mathrm{~min}$ at $72^{\circ} \mathrm{C}$, the PCR products with length $622 \mathrm{bp}$ were digested at $37^{\circ} \mathrm{C}$ for five (5) minutes with $10 \mathrm{U}$ of Hinf1 restriction enzyme.

Restriction digests were electrophoresed at 100 volts for $1 \mathrm{~h}$ on a $2 \%$ agarose gel with ethidium bromide and individual PCR-RFLP fragment sizes in each sample were determined based on a standard DNA molecular weight marker (100bp) by viewing the banding pattern under UV light on the transiluminator. All the three genotypes ( $A A, A B$ and $B B$ ) were found. 


\section{Data collection}

At 10 weeks of age, the Live Body Weight (LBW) of the birds from which the blood samples were collected was determined and slaughtered. The weight of the following carcass traits were also determined using a sensitive scale: Bled weight, Plucked weight, Eviscerated weight, Whole gizzard weight, Empty gizzard weight, Liver weight, Wing weight, Leg weight, Thigh weight, Drum stick weight, Neck weight, Breast weight, Back weight and Head weight.

\section{Statistical Analysis}

Genotypes of individual birds at different base pair (bp) or marker loci were recorded by direct counting of the bands. The gene frequencies were calculated by counting method as follows:

$$
\begin{gathered}
P=\frac{2(A A)+(A B)}{2 N} \\
q=\frac{2(B B)+(A B)}{2 N}
\end{gathered}
$$

Where; $P=$ the gene frequency of allele $A, q=$ the gene frequency of allele $B, N=$ the total number of birds

Obtained results were processed and analyzed using GLM procedure in SAS (SAS. 2010) and means were compared using Duncan's new multiple range test. The statistical model was $Y_{i j}=\mu+$ $\mathrm{G}_{\mathrm{i}}+\varepsilon_{\mathrm{ij}}$

Where: $Y_{i j}$ is the observation of the $i^{t h}$ population, $\mu$ is the population mean, $\mathrm{Gi}$ is the fixed effect of $\mathrm{i}^{\text {th }}$ IGF1 genotype and $\varepsilon_{i j}$ is the random error

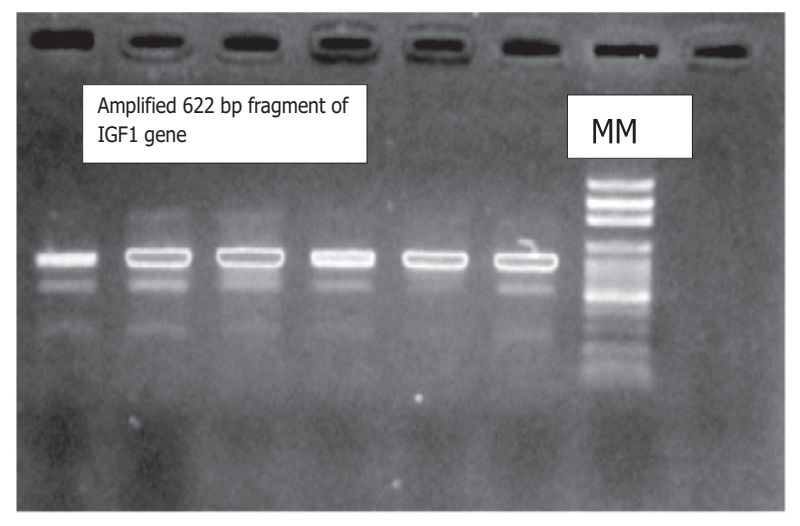

Plate1: IGF-1 gene optimization on agarose gel

\section{Results}

The analysis of variance of effects of /GF-1 gene polymorphism on carcass traits showed that it had no significant $(P>0.05)$ effect on the live body weight before slaughter $(1000.63 \pm 97.02 \mathrm{~g})$, the bled weight $(964.86 \pm 93.89 \mathrm{~g})$, the plucked weight $(904.87 \pm 87.87)$, the eviscerated weight $(722.93 \pm 73.75 \mathrm{~g})$, the thigh

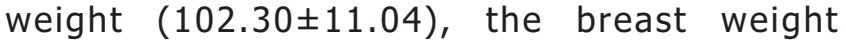
$(154.70 \pm 17.60)$ and the back weight $(145.96 \pm 16.12)$ for genotype $A B$, although higher mean values were observed in these and every other traits considered but the effects were not significant (Table 1). Genotype AA was the next in values to $A B$ for all the traits except for the plucked weight (641.88 \pm 106.69$)$, the leg weight (30.00 \pm 4.32$)$, the breast weight $(98.55 \pm 21.50)$ and the head weight $(27.88 \pm 2.76)$ where the lowest mean values were observed.

Moreover, the lowest mean values were also observed in the genotype BB for all other traits except for the plucked weight (644.57 \pm 194.03$)$, the leg weight (30.71 \pm 9.07$)$, the breast weight $(99.57 \pm 39.09)$ and the head weight (29.14 \pm 5.66$)$ which were higher than genotype $A A$ but less than $A B$, yet the differences were not significant.

Allele and genotype frequencies observed in the analysed samples are given in Table 2. In IGF1 locus, Allelle A was more frequent than B allele with 0.52 and 0.48 respectively. Allele $A$ was identified as a dominant allele in IGF1 locus due to the highest frequency. The frequency of BB homozygous genotype was the lowest among all loci $(0.23)$ whereas $A B$ genotype had the highest frequency of 0.50 as shown in Figure 1.

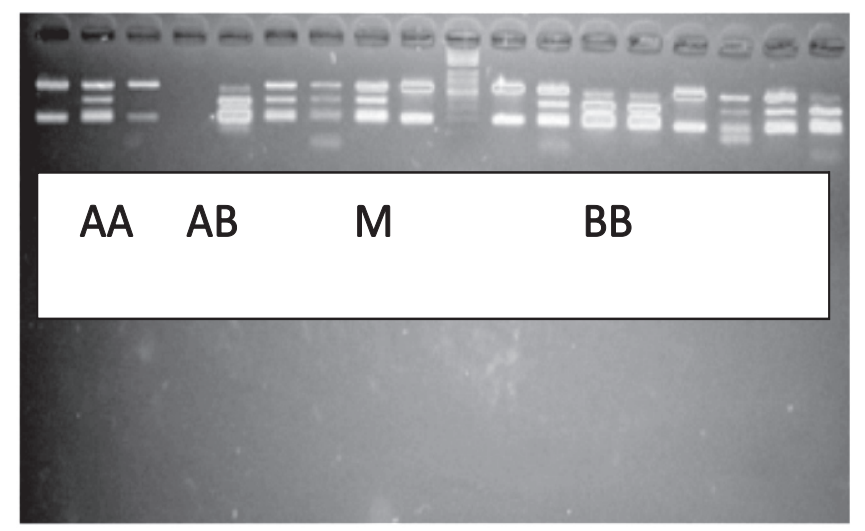

Plate2: IGF-1 gene Polymorphism genotyping 
Table 1: Effect of IGF-1 gene polymorphism on Carcass traits (LSM \pm SE)

\begin{tabular}{llll}
\hline Carcass traits & AA & AB & BB \\
(Grams) & 9 & 30 & 7 \\
\hline & & & \\
Body weight & $764.78 \pm 116.85^{\mathrm{ns}}$ & $1000.63 \pm 97.02^{\mathrm{ns}}$ & $712.00 \pm 212.74^{\mathrm{ns}}$ \\
Bled weight & $681.55 \pm 114.10^{\mathrm{ns}}$ & $964.86 \pm 93.89^{\mathrm{ns}}$ & $680.85 \pm 204.12^{\mathrm{ns}}$ \\
Plucked weight & $641.88 \pm 106.69^{\mathrm{ns}}$ & $904.87 \pm 87.87^{\mathrm{ns}}$ & $644.57 \pm 194.03^{\mathrm{ns}}$ \\
Eviscerated weight & $493.11 \pm 88.85^{\mathrm{ns}}$ & $722.93 \pm 73.75^{\mathrm{ns}}$ & $419.00 \pm 162.32^{\mathrm{ns}}$ \\
Whole gizzard weight & $29.66 \pm 2.96^{\mathrm{ns}}$ & $34.30 \pm 2.39^{\mathrm{ns}}$ & $29.28 \pm 3.98^{\mathrm{ns}}$ \\
Empty gizzard weight & $18.33 \pm 1.69^{\mathrm{ns}}$ & $21.00 \pm 1.55^{\mathrm{ns}}$ & $17.57 \pm 2.80^{\mathrm{ns}}$ \\
Liver weight & $18.44 \pm 2.56^{\mathrm{ns}}$ & $25.03 \pm 2.29^{\mathrm{ns}}$ & $17.42 \pm 4.40^{\mathrm{ns}}$ \\
Wing weight & $62.44 \pm 9.30^{\mathrm{ns}}$ & $89.43 \pm 8.32^{\mathrm{ns}}$ & $60.71 \pm 17.33^{\mathrm{ns}}$ \\
Leg weight & $30.00 \pm 4.32^{\mathrm{ns}}$ & $42.66 \pm 4.15^{\mathrm{ns}}$ & $30.71 \pm 9.07^{\mathrm{ns}}$ \\
Thigh weight & $69.22 \pm 13.65^{\mathrm{ns}}$ & $102.30 \pm 11.04^{\mathrm{ns}}$ & $66.42 \pm 24.47^{\mathrm{ns}}$ \\
Drum stick weight & $67.66 \pm 12.07^{\mathrm{ns}}$ & $94.06 \pm 10.00^{\mathrm{ns}}$ & $66.28 \pm 21.67^{\mathrm{ns}}$ \\
Neck weight & $31.51 \pm 4.31^{\mathrm{ns}}$ & $44.66 \pm 4.37^{\mathrm{ns}}$ & $33.28 \pm 9.67^{\mathrm{ns}}$ \\
Breast weight & $98.55 \pm 21.50^{\mathrm{ns}}$ & $154.70 \pm 17.60^{\mathrm{ns}}$ & $99.57 \pm 39.09^{\mathrm{ns}}$ \\
Back weight & $99.00 \pm 19.66^{\mathrm{ns}}$ & $145.96 \pm 16.12^{\mathrm{ns}}$ & $93.85 \pm 31.24^{\mathrm{ns}}$ \\
Head weight & $27.88 \pm 2.76^{\mathrm{ns}}$ & $33.73 \pm 2.44^{\mathrm{ns}}$ & $29.14 \pm 5.66^{\mathrm{ns}}$ \\
\hline
\end{tabular}

Where $\mathrm{P}>0.05$ show that the value is not significant $\mathrm{ns}=$ non significant

Table 2: Allele and Genotype frequencies

\begin{tabular}{|l|l|l|l|l|l|}
\hline \multirow{2}{*}{ Locus } & \multicolumn{4}{|l|}{ Allele frequencies } & \multicolumn{4}{l|}{ Genotype frequencies } \\
\cline { 2 - 6 } & A & B & AA & AB & BB \\
\hline IGF-1 gene & $\mathbf{0 . 5 2}$ & $\mathbf{0 . 4 8}$ & $\mathbf{0 . 2 7}$ & $\mathbf{0 . 5 0}$ & $\mathbf{0 . 2 3}$ \\
& & & & & \\
\hline
\end{tabular}

\section{Genotype Frequency}

0.6
0.5
0.4
0.3
0.2
0.1
0

Figure 1: Genotypic frequencies of the IGF1 gene polymorphism 


\section{Discussion}

The success of poultry enterprise for meat depends on the level of production at a specific time. The success of selection program for improved meat production depends on the identification of the candidate marker and their successful transfer to the flock of interest. In this study, three genotypes of IGF-1 namely: $A A, A B$, and $B B$ with different fragments using Hinf1 for PCR-RFLP polymorphisms were detected.. The genotype frequency of $A A, A B$ and $B B$ were 0.27 , 0.50 , and 0.23 , respectively and the allelic frequency of A and B were 0.52 and 0.48 , respectively.

In the population of chicken used, the Chisquare for the genotypic frequency was calculated and it was observed that there was no significant difference which shows that the frequency of the genotype does not differ from the expectation of Hardy-Weinberg equilibrium.

Although, polymorphism of IGF-1 shows that it may be a potential candidate gene associated with growth, body composition and carcass traits of chicken (Zhou et al., 2005). Lei et al. (2007) also reported that the IGF-1 polymorphism is also significantly related to the breasts and leg muscles of the chickens but this study shows that there was no significant relationship of the IGF-1 gene mutation with the chicken carcass traits. Although higher mean value were observed in the live body weight, eviscerated weight, breast and back muscles of the chickens with genotype $A B$ but it does not show any significant difference which was also in accordance with the report of Jaromir et al. (2012) that there was no significant difference of the effects of IGF-1 gene on the carcass traits of the broilers used but that higher values were also observed in the breast muscle weight of the $A B$ genotype chickens.

Since, IGF-1 gene could be related with different chicken carcass traits, it is therefore, recommended that further research should be carried out on the investigation of IGF-1 gene and this should be done at specific age as IGF-1 gene could be associated with the body composition and the carcass traits at a particular stage of growth in chickens because this will in no small way improve the economy of the poultry section of the livestock industry in producing more quality carcass traits with higher values.

\section{Acknowledgment}

The authors acknowledge the supports of the PEARL project on Indigenous chicken at the Poultry Breeding Unit of the Federal University of Agriculture, Abeokuta sponsored by Bill and Melinda Gates Foundation.

\section{References}

Afolayan, R.A. forgerty, N.M. (2008). Genetic variation of plasma insulin-like growth factor in young cross breed ewes and its relationship with their maintenance feed intake at maturity and production traits. J.Anim. Sci. 10.2527/jas-0528

Hossein, A. A. and Mohsen K. (2011). Detection of polymorphism at the insulin like growth factor 1gene in Mazandran Native chicken using PCR-RFLP method. American J. Anim. \& Vet. Sci. 6(2):80-83.

Ikeobi, C.O.N., Ebozoje, M.O., Adebambo, O.A., Adenowo, J.A and Osinow, O.A. (1996). Young cross breed ewes and its relationship with their maintenance feed intake. J. Cell. \& Mol. Med. 9(1); 59-71.

Ikeobi, C.O.N., Woolliams, J.A., Morrice, D.R., Law, A., Windso,r D., Burt, D.W. and Hocking, P.M. (2002). Quantitative trait loci affecting fatness in the chicken. Anim. Genet. 33: 428-435.

Jaromir, K., Bozena, H., Vaclav, R., Jindrich, C., Libor, V., Lenka, H. (2011). Insulin-like growth factor-1 gene polymorphism and its association with growth and slaughter characteristics in broiler chickens. J. Agrobiol. 28(2)

Kajimoto, Y. and Rotwein, P. (1991). Structure of the chicken insulin-like growth factor I gene reveals conserved promoter elements. J. Biol. \& Chem. 26: 9724-9731.

Lei M., Luo C., Peng X., Fang M., Nie Q., Zhang D., Yang G. and Zhang X. (2007). Polymorphism of growthcorrelated genes associated with fatness and muscle fiber traits in chickens. Poult. Sci. 86, 835-842.

Nagaraja, S.C., Aggrey, S.E., Yao, J., Zadworny, D., Fairfull, R.W. and Kuhnlein, U. (2000). Brief communication. Trait association of a genetic marker near the IFG-I gene in egg-laying chickens. J. Hered. 91: 150-156.

Nie, W., Wang, J., W.Su, D. Wang, Tanomtong, A., Perelman, P.L., Graphodatsky, A.S. and Yang, F. (2002). Chromosomal rearrangements and karyotype evolution in carnivores revealed by Chromosome painting. Heredity (Edinburg). 108(1): 17- 27

Nwanta, J.A., Umoh, J.U., Abudu, P.A., Agogi, I. and Ali Balogun, J.K (2006). Management of losses performance characteristics of the indigenous chicken of Western Nigeria. Nig. Jour. Anim. Prod. 33:274-285 
Nwosu, C.C. and Asuquo, B.O. (1985). Body weight improvement 'in the Local chicken, Proceedings of the 10th Annual Conference of Nigeria Society for Animal Production. March 24 - 25 Ile-Ife, Nigeria, Pp. 23-29.

SAS. (2010). Statistical Analysis System, Systems for Windows. SAS Institute Inc., Cary.

Shinchi sata, Isuyoshi ohtake, Youshinobu Uemoto, Yumi Okumura and Eiji Kobayashi. (2012). Polymorphism of insulin-like growth factor 1 gene is associated with breast muscle yields in chickens Anim. Sci. J. 83, 1-6.

Sonaiya, E.B. and Olori, V.E. (1990). Village poultry production in South Western Nigeria. Proceeding of an International Workshop held in Ile-ife, Nigeria, November 13-16, 1989, pp; 243-247. Thelia house, Ile-ife.

Sonaiya, E.B., Branckaert, R.D.S. and Gueye, E.F. (1999). Research and development options for family poultry. First INFPD/FAO Electronic Conference on family poultry. The scope and effect of family Poultry Research and Development. http://www.fao.org/WAICENT/FAOINFO/ AGRICULT/AGA/AGAP/ips/fampo/intropap.htm

Zhou, H., Mitchell, A.D., Mcmurtry, J.P., Ashwell, C.M. and Lamoni, S.J. (2005). Insulin-like growth factor-1 gene polymorphism associations with growth body composition, skeleton integrity and metabolic traits in chickens. Poult. Sci. 84, 212-219. 